\title{
Correction to: Identification of the targets of hematoporphyrin derivative in lung adenocarcinoma using integrated network analysis
}

\author{
Hongtao Yin ${ }^{1}$ and Yan Yu ${ }^{2^{*}}$
}

\section{Correction to: Biol Res (2019) 52:4}

https://doi.org/10.1186/s40659-019-0213-z

The Fig. $1 \mathrm{~b}$ is wrongly published in the original publication of the article [1]. The correct version of Fig. 1b is presented in this Correction.

a
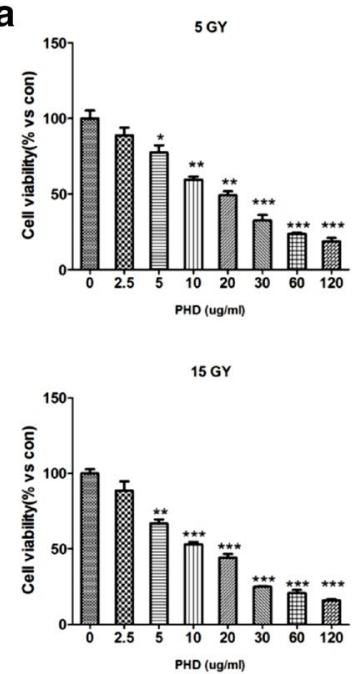

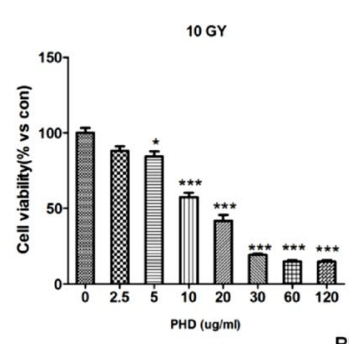

PI
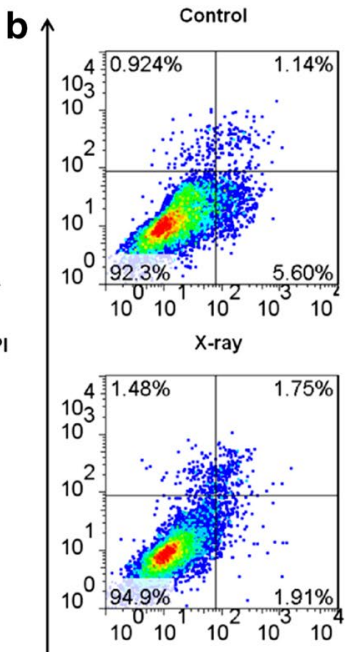

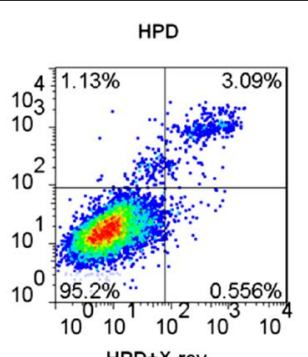

HPD+X-ray

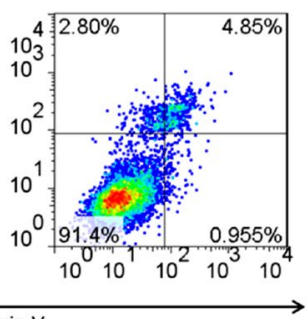

Fig. 1 Effects of the combination of HPD and X-ray. The combination significantly suppressed the proliferation activity (a) and promoted apoptosis of A549 cells (HPD: $10 \mu \mathrm{g} / \mathrm{mL}$; X-ray: 10 Gy irradiation) (b). HPD hematoporphyrin derivative, PI propidium iodide

The original article can be found online at https://doi.org/10.1186/s4065

9-019-0213-z.

*Correspondence: Yuuny_HTH@hotmail.com

${ }^{2}$ Department of Medical Oncology, Harbin Medical University Cancer

Hospital, No. 150 Haping Road, Nangang District, Harbin 150081,

Heilongjiang, China

Full list of author information is available at the end of the article

(c) The Author(s) 2020. This article is licensed under a Creative Commons Attribution 4.0 International License, which permits use, sharing, adaptation, distribution and reproduction in any medium or format, as long as you give appropriate credit to the original author(s) and

the source, provide a link to the Creative Commons licence, and indicate if changes were made. The images or other third party material in this article are included in the article's Creative Commons licence, unless indicated otherwise in a credit line to the material. If material is not included in the article's Creative Commons licence and your intended use is not permitted by statutory regulation or exceeds the permitted use, you will need to obtain permission directly from the copyright holder. To view a copy of this licence, visit http://creativeco mmons.org/licenses/by/4.0/. The Creative Commons Public Domain Dedication waiver (http://creativecommons.org/publicdomain/ zero/1.0/) applies to the data made available in this article, unless otherwise stated in a credit line to the data. 


\section{Author details}

1 Department of Radiation Oncology, Harbin Medical University Cancer Hospital, Harbin 150081, Heilongjiang, China. ${ }^{2}$ Department of Medical Oncology, Harbin Medical University Cancer Hospital, No. 150 Haping Road, Nangang District, Harbin 150081, Heilongjiang, China.

Published online: 19 April 2020

\section{Reference}

1. Yin H, Yu Y. Identification of the targets of hematoporphyrin derivative in lung adenocarcinoma using integrated network analysis. Biol Res. 2019:52:4. https://doi.org/10.1186/s40659-019-0213-z.

\section{Publisher's Note}

Springer Nature remains neutral with regard to jurisdictional claims in published maps and institutional affiliations.
Ready to submit your research? Choose BMC and benefit from:

- fast, convenient online submission

- thorough peer review by experienced researchers in your field

- rapid publication on acceptance

- support for research data, including large and complex data types

- gold Open Access which fosters wider collaboration and increased citations

- maximum visibility for your research: over $100 \mathrm{M}$ website views per year

At BMC, research is always in progress.

Learn more biomedcentral.com/submissions 